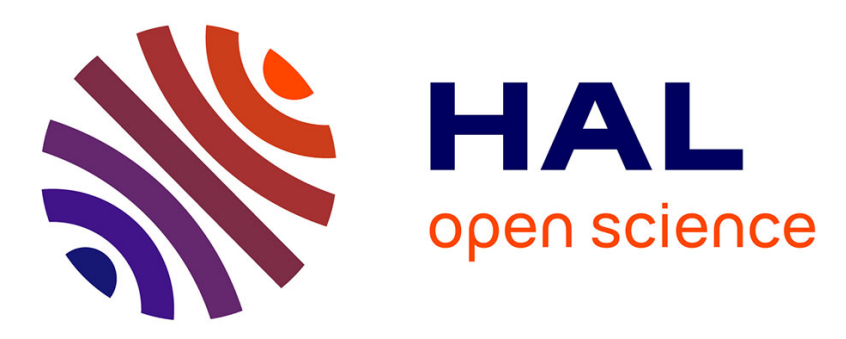

\title{
Mambalgins, Snake Peptides Against Inflammatory and Neuropathic Pain Through Inhibition of ASIC Channels
}

Anne Baron, Sylvie Diochot, Miguel Salinas, Abdelkrim Alloui, Dominique

Douguet, Gilles Mourier, Pascal Kessler, Enrico Stura, Thomas Besson, Valérie Friend, et al.

\section{To cite this version:}

Anne Baron, Sylvie Diochot, Miguel Salinas, Abdelkrim Alloui, Dominique Douguet, et al.. Mambalgins, Snake Peptides Against Inflammatory and Neuropathic Pain Through Inhibition of ASIC Channels. Toxicon, 2018, 149, pp.93. 10.1016/j.toxicon.2017.12.026 . hal-02368770

\section{HAL Id: hal-02368770 https://hal.science/hal-02368770}

Submitted on 18 Nov 2019

HAL is a multi-disciplinary open access archive for the deposit and dissemination of scientific research documents, whether they are published or not. The documents may come from teaching and research institutions in France or abroad, or from public or private research centers.
L'archive ouverte pluridisciplinaire HAL, est destinée au dépôt et à la diffusion de documents scientifiques de niveau recherche, publiés ou non, émanant des établissements d'enseignement et de recherche français ou étrangers, des laboratoires publics ou privés. 


\section{Mambalgins, Snake Peptides Against Inflammatory and Neuropathic Pain Through Inhibition of ASIC Channels}

Anne Baron ${ }^{1,2}$, Sylvie Diochot ${ }^{1,2}$, Miguel Salinas ${ }^{1,2}$, Abdelkrim Alloui ${ }^{3}$, Dominique Douguet ${ }^{1}$, Gilles Mourier $^{4}$, Pascal Kessler ${ }^{4}$, Enrico A. Stura ${ }^{4}$, Thomas Besson ${ }^{1,2}$, Valérie Friend ${ }^{1,2}$, Denis Servent ${ }^{4}$, Alain Eschalier $^{3}$, Eric Lingueglia ${ }^{1,2}$

${ }^{1}$ Université Côte d'Azur, CNRS, Institut de Pharmacologie Moléculaire et Cellulaire, Valbonne, France ;

${ }^{2}$ LabEx Ion Channel Science and Therapeutics, Valbonne, France ;

${ }^{3}$ Université d'Auvergne, Inserm, NEURO-DOL, Clermont Ferrand, France ;

${ }^{4}$ Commissariat à l'Energie Atomique, iBiTecS, Gif-sur-Yvette, France ;

Mambalgins are 57-amino acid peptides isolated from mamba venom. They produce potent analgesic effects in mice against inflammatory pain upon central intrathecal (i.t.), and peripheral local (i.pl.) injections, through inhibition of different ASICs subtypes and involvement of opioid-independent pathways. They produce fewer side effects than morphine and no apparent toxicity.

We now show that mambalgins also have an opioid-independent effect on both thermal and mechanical pain upon systemic intravenous (i.v.) administration and are effective against neuropathic pain by i.v., i.t. and i. pl. injections. By combining the use of knockdown and knockout animals, we show the critical involvement of peripheral ASIC1b-containing channels in the i.v. effects of mambalgins against inflammatory pain. The potent analgesic effect on neuropathic pain involves two different mechanisms depending on the route of administration, a naloxone-insensitive and ASIC1aindependent effect associated with i.v. injection, and an ASICla-dependent and partially naloxonesensitive effect associated with i.t. injection.

We have done in collaboration with the CEA iBiTecS Institute in Gif-sur-Yvette, the full stepwise solid-phase peptide synthesis of mambalgin-1, solved its 3D crystal structure, mapped the pharmacophore, and identified the binding site and the inhibitory mechanism on ASICla channels.

These findings identify new roles for ASICs in pain pathways, and mambalgins as new potential analgesics against inflammatory and chronic neuropathic pain. 